\title{
New Realia of East-Ukrainian Education Internationalization: Provision of Technical and Vocational Training, Including Skill Development for Adults' Re-Deployment
}

\author{
I. V. Myhovych \\ State Institution Luhansk Taras Shevchenko National University, Starobilsk, Ukraine \\ Corresponding author. E-mail: irina.migovich@gmail.com
}

Paper received 29.08.19; Accepted for publication 10.09.19.

\begin{abstract}
https://doi.org/10.31174/SEND-PP2019-203VII83-05
\end{abstract}
\begin{abstract}
The article is devoted to the investigation of the process of internationalization within the context of east-Ukrainian higher and vocational education. Since 2011 the Ministry of Education and Science of Ukraine has transferred powers and funds for initial vocational training of workers to the regional level. However, a mechanism to monitor the needs of the regional labour market has not been created in any oblast of Ukraine. Thus, vocational schools now provide training without any information about the estimated number of workers in different professions required by regional employers. At the same time research on employers' needs (the regional labour market) can provide a validation base for the allocation of funds for training from the state (regional) budget.
\end{abstract}

Keywords: Internationalization, East-Ukrainian Education, Technical and Vocational Training, European Union, International Programme.

Introduction. Today, the issue of providing personnel for the country's economy as a whole and the activities of basically all of its enterprises in particular, are showing the striking sign of becoming a threat to the national security of Ukraine. The outflow of hundreds of thousands of skilled workers who are at their most productive age, the mismatch between training curricula and the labour market's needs for skilled labour, and the discrepancy between the vocational qualifications of recognized educational institutions' graduates and the requirements of employers have lead to a threatening situation that undermines the country's investment activity and attractiveness, reduces exports and the competitiveness of domestic products and services, causes an outflow of capital and the impoverishment of the population, and decreases productivity. The most critical situation with these issues among the country's educational systems is observed in vocational education, in which the authorities, the state, and the regions were largely not involved after the Soviet Union collapsed (schools' loss of local companies, the falling prestige of workers' occupations, the emergence of ultra-easy access of young people to formal higher education, etc.). These issues are becoming particularly germane for the eastern part of Ukraine, where the problems of national vocational education development have been compounded by the extraordinarily heavy burden of the events, consequences, and present difficulties caused by some areas of Donetsk and Luhansk oblasts not being under government control. The relevance of this study lies in the search for a resolution to the current situation.

The goal. Based on the aforementioned, the goal of the study is to analyze and identify the top-priority issues of Luhansk Oblast's vocational education and training (VET) system and their relevance to the needs of the regional labour market, as well as to develop a set of recommendations for a broad range of stakeholders to use to resolve them. To achieve this goal, the following tasks were identified and implemented: - to study and analyze the impact of the changing socio-economic status of Luhansk Oblast as a whole, and the demographic situation in particular, on the VET system; - to analyze the employment situation of the population, the functioning of the regional and local labour markets, to identify key trends, parameters and the extent of their impact on the development of the educational sphere of the oblast and its territories, and primarily its vocational segment; - to assess the results, problems (and their causes), and trends in the oblast's educational institutions by sector, type, and form of subordination; - to consider in detail the components of the vocational education and training (VET) system (personnel; logistical, institutional, functional, legislative and normative support; the degree to which vocational training of workers meets the needs of the labour market, the use of the latest training programs and forms, etc.); - to carry out a rating assessment of the activity, resources, and personnel potential of agricultural and non-agricultural VET institutions, for possible international support for the modernization of the best of them, taking into consideration the whole range of factors and selection criteria; - to conduct a sociological survey of managers, workers, and students of Luhansk Oblast VET institutions on the evaluation of the Luhansk Oblast VET institution system's current state and development prospects; - to calculate, as an example, the degree to which the curricula at VET institutions meet the needs of local labour markets; - to prepare conclusions and submit proposals for modernizing this sphere of education based on the needs of the regional labour market.

Materials and methods. The methodological basis of the study was as follows: the research methodology coordinated with experts of the project and focused on the use of statistical data on key indicators of the socio-economic and demographic development of the oblast and its administrative units. The data used included that on employment and the labour market (especially the youth segment); educational services, in terms of type, form, and subordination of educational institutions in 2005, 2010, 2015 and the following years, etc.; formal statistics and operational data provided by the statistical authorities, employment centres, the Department of Education and Science, VET (TVET) institutions for further analysis and comparison; the findings of a study carried out under the auspices of the Ministry of Education and Science of Ukraine and the European Foundation for Education (EFE) on: "The Torino Process in Ukraine: Regional Level-Analysis of the Luhansk Oblast VET System for 2016-2017" (37 sources of information were used); online surveys on three types of questionnaires 
for managers, employees, and students of VET institutions, based on the use of Google Form Software; the author's methodological work: Methodology for evaluating the activities of VET (TVET) institutions in Luhansk and Donetsk Oblasts regarding the alignment of educational curricula and regional labour market demand; methodical recommendations for determining the correspondence of the level and vocational qualification structure of personnel training in educational institutions, based on the needs of the regional labour market; and methodological approaches to determining the needs of the oblast for labour over the short-term.

Results and discussion. The conducting of the survey produced the following main results:

1. The loses to Luhansk Oblast of resources - including socio-economic, demographic, personnel, institutional, intellectual potential, loss of territories, educational institutions, etc. - due to the armed conflict and its consequences were identified. On average, the volume of all such losses varies from approximately 3.5-5.0 times, while the most painful are the loss of two-thirds of the oblast's population and almost $90.0 \%$ of its large industrial companies.

2. It has been found that the demographic situation in Luhansk Oblast in most areas is the worst in the country. This certainly has a very negative impact on the issue of the shortage of applicants to VET institutions, the growing acute competition for attracting this category of young people between universities, colleges, and VET institutions, and between VET institutions and general secondary education institutions for 9th-grade graduates (Figure 1).

3. Based on the analysis of the socio-economic development of Luhansk Oblast, the author identifies six priority economic/vocational activities: agriculture, agricultural production, construction, reconstruction and recovery of post-war ruined real estate; coal mining and other sub-sectors of the mining industry; rehabilitation of the environment; energy saving, energy efficiency and the development of renewable energy; rehabilitation of areas and population from the consequences of the armed conflict; and services (social segment), and small- and medium-sized enterpises by sector. The author also lists the new occupations (positions, titles of jobs) related to these activities, for which many educational institutions around the country are already carrying out the training of labour.

4. The employment of the population and the state of the regional and local labour markets in terms of vocational, gender/age, and functional sections were analysed. The main reasons for the formation of negative trends in Luhansk Oblast's regional labour market (which are not inherent to other regions of the country apart from Donetsk Oblast, to some extent) include: a) the armed conflict, and the resulting significant losses of potential for further development, limited investment, etc. It is clear that this situation leads to a continuous increase of the labour outflow and migration of the most able-bodied age groups to other regions of the country and beyond; b) as noted above, the oblast's demographic situation is the worst of all the regions of Ukraine, which has a direct and damaging impact on the labour potential of Luhansk Oblast; c) fundamental changes in the sectoral structure of the employment market; the growth of its informal segment; the "shadow" economy; the negative consequences of the socially unprotected and financially unjustified closure of mines; significant differences in the spatial structure of economic activity ; and the single-industry specialization of most small towns and urban localities; d) widespread social apathy, the desire to remain in a state of dependence among many strata of the population; e) dependence of the regional labour market on a rather large segment of workers employed in the mode of circular labour migration, rotation, temporary or part-time employment, including in the informal sector of the economy, while living in non-government-controlled territories; f) a high level of motivation among young people to leave and to study in other oblasts, EU countries (primarily Poland and the Czech Republic), as well as the neighboring Russian Federation, and to put down roots there in the future; g) the gradually falling number of IDPs in the oblast (from 292,800 persons in 2017 to 286,900 persons in 2018) and their share in Ukraine (from $19.6 \%$ to $19.4 \%$, respectively), which to a small extent also reduces the labour potential of the oblast; $h$ ) an underdeveloped network of employment centres (enterprises).

5. The following is characteristic of the activity of the oblast and local level employment centres for training: dynamic growth (starting in 2015) of the number of unemployed persons referred for vocational training, which exceeded the 2015 figure by one-and-a-half times in 2018 (3,958 and 2,570 persons, respectively), and the level of employment of this category of unemployed (from $82.6 \%$ to $91.2 \%$, respectively); providing of professional orientation guidance for unemployed persons on regular basis over the years; constant increase of involvement of unemployed youth in community work; the de facto curtailment (as well as throughout the country) of the practice of providing unemployed persons with vocational and continuing vocational training vouchers and one-time unemployment benefits to start up entrepreneurial activities; and an increase in the number and proportion of employers who work with employment centres.

6 . It has been determined that youth unemployment in the oblast has seen a decrease in the share of graduates of educational institutions among the unemployed; there is rather high youth unemployment compared to other age groups; there has been a decrease in the proportion of unemployed young people due to the work of employment centres; an increase in the proportion of young people employed for newly created workplaces with the employment centers' compensation of employers' SSC payment expenses for all in this category of employed respectively ; an increase in career guidance activities for students of educational institutions; and a decrease in the proportion of unemployed young people in the general unemployed population registered at employment centres.

7. There is evidence of a certain detachment of universities (unlike most technical schools/colleges and vocational schools) from the needs of the regional labour market. This is clearly shown by the share of local residents in the total number of students of higher education institutions, as well as by high percentage of military personnel involved in the Joint Forces (JF) among full-time and parttime students, whose qualitative attendance of study causes certain doubts. There is also a tendency for the further "draining" of school graduates to higher education institutions due to the "ease" of studying there.

8. The state, problems, and prospects for development of the oblast VET system and institutions were reviewed, 
revealing: - $\quad$ a significant reduction in the number of students at oblast VET institutions over the review period (5.2 times fewer in 2017 compared to 2010), and a dynamic reduction over the last four years, which is a general trend in the country; - the number of oblast VET staff, primarily pedagogical workers, has been increasing (by filling vacancies) over the last year, although this is small in volume; the author failed to find examples of significant overproduction of certain categories of the workforce by the TVET institution in the oblast. In cases where certain professions are not in demand among employers, the management of TVET Institutions and vocational education authorities of the oblast make appropriate decisions to reduce the number of applicants or to otherwise curtail training. For example, over the past two years, individual VET Institutions have reduced the number of students for professions like (bank) cashier, information processing and software operator, office worker (accounting), typesetting operator, and others that are not in demand in the local labour market; - in 2018, the top ten most popular working professions in VET (cook, tractor driver for agricultural (forestry) production, pastry chef, driver, electric gas welder, repair mechanic of agricultural machines, hairdresser (hairdresser/hair stylist), plasterer, nail technician and painter) accounted for $57.2 \%$ of the total number of graduates. Thus, most of the vocational training programs of Luhansk VET institutions focus on a highly diversified set of labour professions, that is, they are aimed at those who get professional qualifications gaining the possibility for self-employment or starting their own business.

9. The author has studied match between training types and levels of labour personnel and the needs of the local labour market. This approach shows that the educational authorities, VET Institutions, and local employment centres could use in practice the author's methodical approaches after they have been refined and studied. According to calculations, among an aggregated 96 areas of training in labour professions for 21 out of 22 oblast VET institutions, in 10 cases $(10.4 \%)$, it is proposed to increase the amount of training by 1.2-1.5 times; for almost half of the professions ( $46 \%$ or $47.9 \%$ ), it is recommended to maintain training at its present levels; in 18 cases $(18.8 \%)$, it is proposed to reduce the number of applicants; and for 22 professions $(22.9 \%)$, it is recommended to suspend or curtail the admission of students (which has already been done by individual VET institutions).

Conclusions. The research has made it possible to reach the following conclusions:

1. Despite enormous difficulties, primarily due to underfunding, the ill-conceived and badly prepared decentralization of VET institutions resulting in the transfer of problems from the centre to the regions, insufficient assistance from the state for the socio-economic development of Luhansk and Donetsk oblasts, which were the most seriously affected by the armed conflict, and many other disadvantages, VET institutions have demonstrated their viability and motivation to make innovative changes, and also maintain and expand their infrastructure, labour potential, and cooperation with employer partners, etc.

2 . With the reduction in their demographic potential, the number of students, in particular those who pay for their education, will decrease (in the 2018-2019 academic year, Luhansk universities accepted 1.3 times more paying students than those who study for free as state budget funded students). The importance of state funding for educational institutions will increase). The competition of educational institutions for the student contingent is going to grow.

3. Before the conflict, Luhansk Oblast had significant economic potential and was one of the five most powerful industrial and economic regions of Ukraine, whereas now it is in last place according to most of the country's socioeconomic indicators. Today, Luhansk Oblast is being shaped as an agricultural area with distinct "hints" of industry.

5. A review of the sphere of employment trends and the economic activity of the able-bodied population in the labour market of Luhansk Oblast over the past 15 years throws up some rather ambiguous features that could have a significant influence on the training of personnel. In general, there have been positive trends in the labour market declining unemployment and growth of employment and occupations, including those that are not always able to compete on equal terms for vacancies and jobs.

6. Youth unemployment in the oblast has improved overall in most indicators over the past two years, mainly due to the reduced burden on labour markets from VET institution graduates.

7. Based on the study of the state of development of the VET education system, the prospects for the expansion of the VET institutions to 22 units are exhausted. With the further development and rehabilitation of the economic potential of Luhansk Oblast, the training of personnel will be an important factor, including through the VET network. However, it is proposed to stop optimizing them until there are the appropriate conditions.

8. In Luhansk Oblast, as well as throughout Ukraine, VET institutions also carry out an important and socially significant function: educating and raising orphans and other socially vulnerable groups of young people.

According to the results of the study, the following key proposals have been prepared:

At the level of state:

1. Accelerate, adopt, and implement the Law of Ukraine "On Vocational Education," which will enable regions to implement fully the measures aimed at modernizing the VET system, the need and the relevance of which is of primary importance for the work of VET institutions.

2. Ensure the development and practical implementation of effective legislative, financial, investment, personnel, intellectual, infrastructure, etc. mechanisms of support for the restoration and development of government-controlled areas of Luhansk Oblast, employment and social security of internally displaced persons (IDPs), residents of areas along the contact line, and the stimulation of the creation of new productive jobs, primarily in the small- and medium-sized business sector.

3. Initiate the elaboration and adoption of a legislative act on the financing of the predominantly state-owned VET institutions and higher education institutions in Luhansk and Donetsk oblasts (with a diversified, mixed approach), as part of the recovery and development of the governmentcontrolled areas of Luhansk Oblast and to preserve intellectual, cultural, and other resources of most administrative districts of the oblast.

At the level of the Ministry of Education and Science of 


\section{Ukraine:}

4. As a beneficiary of the EU Infrastructure Project on Assistance in reforming the system of vocational education in Ukraine (the EU project "EU4Skills"), include, as a priority, measures to support Luhansk and Donetsk oblast VET institutions, first of all during the creation of a network of centres of excellence and innovation; form a system for forecasting the need for professional qualifications at the regional level; the creation of cases of dual form of training usage, etc.

5. Accelerate the development and implementation of normative, methodological, and guidance documents in the field of regulation of the VET, the absence of which makes the effective functioning of VET institutions impossible (for example, methodology for the development of standards for VET on the basis of professional standards, forecasting levels and areas of training of working personnel in accordance with the needs of the regional labour markets, etc.).

6. Compile on the ministry's website a convenient and complete database of normative acts, forecasts of labour market needs, a list of a substantial part of the accepted professional standards and the standards of professional education in certain professional qualifications, educational and training programs, etc., which would allow the country's VET institutions to save time and material resources when implementing new, innovative approaches.

At the regional level and at the vocational education institutions level:

7. Suspend for the next two or three years the processes of optimizing VET institutions in Luhansk Oblast, so as to retain the existing network as a basis for the training of labour personnel when the region returns to economic growth.

8. To finalize and implement three original methodological developments tested in this study: a) The methodology for evaluating the activity of VET institutions in Luhansk and Donetsk oblasts regarding the compliance of the training of workers and technical staff to the needs of the regional labour markets; b) The methodical recommendations for determining the correlation between the amounts and professional qualifications structure of VET institutions personnel training according to the regional labour market's demands; c) The methodological approaches for determining the region's labour force needs over the shortterm.

9. To expand the network of VET institutions utilizing the dual form of education in work practice.

10. For the authorities and employers to gradually move to personnel training when formulating a regional training order. This includes training labour professions in the priority areas of the region's economic development that were identified in the study (agriculture, agricultural production, construction, reconstruction and recovery of post-war ruined real estate; coal mining and other sub-sectors of the mining industry; environmental rehabilitation; energy saving, energy efficiency and renewable energy; services (social segment), small- and medium-sized businesses for various types of economic activity).

\section{REFERENCES}

1. Beelen J. Redefining Internationalization at Home. - J. Beelen, E. Jones // The European Higher Education Area: Between Critical Reflections and Future Policies, 2015. - Springer International. - P. 326.

2. Fielden J. Lite Practice of Internationalization: Managing International Activities in UK Universities. - UK Higher Education International Unit, 2008. - P. 67.

3. Goddard S. E. Uncommon Ground: Indivisible Territory and the Politics of Legitimacy. - International Organization, 2006. - Vol. 60. - P. 35 - 68.

4. Knight J. Internationalization Re-Modelled: Definition,

Approaches, and Rationales. - Journal of Studies in International Education, 2004. - No. 8, (1). - P. 5 - 31 .

5. Wit K. de. The Consequences of European Integration for Higher Education. - Higher Education Policy, 2003. - No. 16 (2). - P. $101-178$.

6. Zhyliayev I. B. Higher Education in Ukraine: State and Problems / I. B. Zhyliayev, V. V. Kovtunets, M. V. Syomkin. Kyiv: Institute of Higher Education of the National Academy of Pedagogical Sciences of Ukraine, 2015. - P. 88. 